\title{
EXAFS Characterization of New Active Phases for Catalytic Hydrotreatment: Two Cations Disulfide Layers in the $\mathrm{Mo}_{\mathrm{x}} \mathrm{W}_{(1-\mathrm{x})} \mathrm{S}_{2}$ Lamellar Solid Solution
}

\author{
C. Thomazeau', C. Geantet ${ }^{2}$, M. Lacroix², M. Danot ${ }^{3}$ and V. Harle ${ }^{1}$ \\ 1 IFP-Lyon, BP 3, 69390 Vernaison - France \\ 2 IRC-CNRS, 2 avenue Albert Einstein, 69626 Villeurbanne - France \\ 3 IMR, UMR 6502, CNRS-Univ. Nantes, 2 rue de la Houssinière, 44322 Nantes - France \\ e-mail: cecile.thomazeau@ifp.fr - christophe.geantet@catalyse.univ-lyon 1.fr - lacroix@catalyse.cnrs.fr - \\ michel.danot@cnrs-imn.fr, virginie.harle@eu.rhodia.com \\ * corresponding author
}

Résumé - Caractérisation par EXAFS de nouvelles phases actives pour l'hydrotraitement catalytique : les couches disulfures à deux cations de la solution solide lamellaire $\mathbf{M o}_{\mathrm{x}} \mathrm{W}_{(1-\mathrm{x})} \mathbf{S}_{\mathbf{2}}$ Des composés $\mathrm{Mo}_{0.5} \mathrm{~W}_{0.5} \mathrm{~S}_{2}$ ont été préparés à l'état massique et à l'état dispersé sur alumine. L'absorption X, seule technique permettant d'obtenir cette information, montre que les deux cations Mo et $\mathrm{W}$ sont présents au sein de chaque couche $\left[\mathrm{MS}_{2}\right]$, selon un modèle de solution solide intrafeuillet. L'intérêt de ce système mixte est de pouvoir moduler la force de liaison Métal-Soufre considérée comme le paramètre clé de l'activité catalytique des sulfures de métaux de transition. Cette solution solide est toujours présente après promotion par le Ni des systèmes massiques ou supportés sur alumine.

\footnotetext{
Abstract - EXAFS Characterization of New Active Phases for Catalytic Hydrotreatment: Two Cations Disulfide Layers in the $\mathbf{M o}_{x} \boldsymbol{W}_{(1-x)} S_{2}$ Lamellar Solid Solution-Bulk and alumina-supported $\mathrm{Mo}_{0.5} \mathrm{~W}_{0.5} \mathrm{~S}_{2}$ compounds were prepared. The presence of both molybdenum and tungsten in every $\left[M S_{2}\right]$ layer (intralayer solid solution) was evidenced using EXAFS spectroscopy, the only local method which can provide such relevant structural information. The catalytic interest of such solid solution is to provide a continuous variation of M-S bond strength which is considered as the key parameter of the catalytic activity transition metal sulfides. The solid solution is maintained after promotion by Ni either on unsupported or supported state.
} 


\section{INTRODUCTION}

Environmental legislation [1] concerning emissions of $\mathrm{SO}_{x}$ and $\mathrm{NO}_{x}$ gas becomes more and more drastic. In most advanced countries, the diesel sulfur allowable limit will be as low as $50 \mathrm{wppm}$ this year and probably $10 \mathrm{wppm}$ before 2010. In order to abide by these stringent rules, tremendous research efforts are made in both fields of formulation of new hydrotreating catalysts and design of new processes.

Catalytic activities of various transition metal sulfides have been shown to be related to the M-S bond strength according to volcano curve trends [2-4]. Use of such a M-S bond descriptor thus opens new perspectives for the design of catalytic active phases [4]. Effectively, it appears that catalytic activity could be improved by pertinent adjustment of the M-S bond energy. Such an adjustment could be achieved through synthesis of solid solutions involving two transition metal sulfides with different cations.

\section{EXAFS SPECTROSCOPY, A POWERFUL TOOL FOR THE CHARACTERIZATION OF LAMELLAR DISULFIDES SYSTEMS}

In the field of hydrotreating catalysts, active phases are based on the use of lamellar disulfides such as $\mathrm{MoS}_{2}$ or $\mathrm{WS}_{2}$ dispersed on alumina and promoted by Co or Ni. In such $\mathrm{MS}_{2}$ lamellar transition metal disulfides, the structural unit is a layer constituted by three hexagonal atomic planes, a cationic one "sandwiched" by two anionic ones [5]. Within the layer, every $\mathrm{M}$ atom is surrounded by a sulfur trigonal prism consisting of six crystallographically equivalent sulfur atoms. The crystals result from stacking of such layers along the $c$-axis according to the scheme [S-M-S] $\infty$. Such structures are highly anisotropic because strong iono-covalent metal-sulfur bonds within the S-M-S layer coexist with weak interactions between adjacent layers (this weakness explains the inter-layer space to be known as the van der Waals gap).

As discussed above, it can be interesting to try to associate $\mathrm{W}$ and Mo in a lamellar disulfide solid solution $\mathrm{Mo}_{\mathrm{x}} \mathrm{W}_{(1-\mathrm{x})} \mathrm{S}_{2}$, as it was already done with $\mathrm{Nb}$ and $\mathrm{Mo}\left(\mathrm{Nb}_{\mathrm{x}} \mathrm{Mo}_{(1-\mathrm{x})} \mathrm{S}_{2}\right.$ solid solution [6]). A priori, two structural models can be envisioned for such solid solutions involving two cations, $\mathrm{M}^{\mathrm{a}}$ and $\mathrm{M}^{\mathrm{b}}$ :

- every layer can contain only one type of cation and the mixed system results from stacking of homocationic $\left[\mathrm{M}^{\mathrm{a}} \mathrm{S}_{2}\right]$ and $\left[\mathrm{M}^{\mathrm{b}} \mathrm{S}_{2}\right]$ layers (interlayers solid solution);

- or the two cations can be present in every layer and the mixed system arises from stacking of heterocationic $\left[\mathrm{M}_{\mathrm{x}}^{\mathrm{a}} \mathrm{M}_{(1-\mathrm{x})}^{\mathrm{b}} \mathrm{S}_{2}\right]$ layers (intralayer solid solution).

A third possibility is that the synthesis attempt was unsuccessful and led to a two phase system $\left(\mathrm{M}^{\mathrm{a}} \mathrm{S}_{2}+\mathrm{M}^{\mathrm{b}} \mathrm{S}_{2}\right)$. If well-crystallized compounds are concerned, X-ray diffraction technique could be expected to be an efficient tool for structural study.

For a $\mathrm{M}_{\mathrm{x}}^{\mathrm{a}} \mathrm{M}^{\mathrm{b}}{ }_{(1-\mathrm{x})} \mathrm{S}_{2}$ solid solution, however, the position of the diffraction lines cannot allow to choose between the interlayers and intralayer models, due to the statistical character of the $\mathrm{X}$ ray-diffraction technique. Effectively, in both cases, the refined cell parameters will be found to be intermediate between those of $\mathrm{M}^{\mathrm{a}} \mathrm{S}_{2}$ and $\mathrm{M}^{\mathrm{b}} \mathrm{S}_{2}$ and to depend upon $\mathrm{x}$, according to the Vegard's law which should be obeyed, at least approximately. In the cases of ordered arrangements of the $\mathrm{M}^{\mathrm{a}}$ and $\mathrm{M}^{\mathrm{b}}$ cations within the $a$ - $a$ plane of a layer (intralayer solid solution) or of the $\left[\mathrm{M}^{\mathrm{a}} \mathrm{S}_{2}\right]$ and $\left[\mathrm{M}^{\mathrm{b}} \mathrm{S}_{2}\right]$ layers along the $c$-axis (interlayers solid solution), superstructure reflexions concerning respectively $a$ or $c$ would provide valuable information. However, to our knowledge, XRD study of such systems never evidenced any superstructure line, even for particular $\mathrm{M}^{\mathrm{a}} / \mathrm{M}^{\mathrm{b}}$ atomic ratios. Furthermore in the case of supported catalysts, no XRD lines are detected due to the nanosize of the lamellar crystallites.

Identification of a two phase system $\left(\mathrm{M}^{\mathrm{a}} \mathrm{S}_{2}+\mathrm{M}^{\mathrm{b}} \mathrm{S}_{2}\right)$ from XRD results appears on the contrary very easy since the diffraction pattern will contain both sets of the two disulfide component diffraction lines. It is effectively what is observed when $\mathrm{NbS}_{2}$ and $\mathrm{MoS}_{2}$ coexist [6]. However, for $\mathrm{WS}_{2}$ and $\mathrm{MoS}_{2}$, no conclusion can be drawn because the diffraction lines of these two disulfides are so close (Table 1) that it is impossible to decide whether the pattern contains a unique

TABLE 1

Crystallographic parameters of the $2 \mathrm{H}$ varieties ( $\mathrm{SG}: \mathrm{P}_{3} / \mathrm{mmc}$ ) and atomic distances of $\mathrm{NbS}_{2}, \mathrm{WS}_{2}$, and $\mathrm{MoS}_{2}$ (from ICSD database)

\begin{tabular}{l|c|c|c}
\hline & $\mathrm{MoS}_{2}-2 \mathrm{H}$ & $\mathrm{WS}_{2}-2 \mathrm{H}$ & $\mathrm{NbS}_{2}-2 \mathrm{H}$ \\
\hline $\mathrm{a}(\AA)$ & $3.161(12)$ & 3.154 & 3.31 \\
$\mathrm{c}(\AA)$ & $12.298(5)$ & 12.362 & 11.89 \\
Cation atomic position & $(1 / 3,2 / 3,1 / 4)$ & $(1 / 3,2 / 3,1 / 4)$ & $(0,0,1 / 4)$ \\
Sulfur atomic position & $(1 / 3,2 / 3,0.621(4))$ & $(1 / 3,2 / 3,0.6225)$ & $(1 / 3,2 / 3,0.125)$ \\
Distance M-M $(\AA)$ & 3.161 & 3.154 & 3.31 \\
\hline Distance M-S $(\AA)$ & 2.41 & 2.41 & 2.42 \\
\hline
\end{tabular}


line set (solid solution) or two unresolved line sets (two phase system).

In this case, the problem can be solved using Energy Dispersive X-ray Spectroscopy (EDX or EDXS) analysis: for a two phase system, rather large one cation domains are observed while, for a solid solution, the two cations are found to coexist even for the smallest probe sizes.

The conclusion is that a two phase system can always be identified. If XRD sometimes cannot, EDX analysis always can. On the contrary, interlayers and intralayer solid solutions cannot be distinguished from each other, neither from XRD nor from EDX analysis, and only a local method such as EXAFS can provide relevant information.

For a disulfide system, the EXAFS spectrum at the cation edges consists of two contributions respectively related to the anion and cation in-layer neighbours of the absorbing atom. The neighbours in adjacent layers are located at high distances from the absorbing atom and, except for highlyorganized phases (which are not of paramount interest in catalysis), do not significantly contribute to the EXAFS signal, as shown by the Fourier transform (FT) of the EXAFS spectrum, which contain only the two in-layer peaks. It is the second peak (in-layer cation neighbours) which can be expected to allow the solid solution type to be identified. For an interlayer solid solution, the $\mathrm{M}^{\mathrm{a}}$ absorbing cation will "see" only $\mathrm{M}^{\mathrm{a}}$ neighbours and the $\mathrm{M}^{\mathrm{b}}$ absorbing cation only $\mathrm{M}^{\mathrm{b}}$ neighbours, just as in the case of a two phase system (homocationic layers in both cases). On the contrary, for an intralayer solid solution, both $\mathrm{M}^{\mathrm{a}}$ and $\mathrm{M}^{\mathrm{b}}$ absorbing cations will "see" $\mathrm{M}^{\mathrm{a}}$ and $\mathrm{M}^{\mathrm{b}}$ neighbours since these two cations are present in every layer. It follows that EXAFS is not the relevant tool to choose between the hypothesis of a two phase system and that of an interlayers solid solution (it is not very important since the information can be obtained from EDX analysis) but perfectly allows interlayer and intralayer solid solutions to be distinguished.

This can be illustrated by the $\mathrm{Nb}_{\mathrm{x}} \mathrm{Mo}_{(1-\mathrm{x})} \mathrm{S}_{2}$ and $\mathrm{Mo}_{\mathrm{x}} \mathrm{W}_{(1-\mathrm{x})} \mathrm{S}_{2}$ series, and it will be seen that, depending upon the two cations involved, the information obtained is different but in both cases allows the nature of the material to be clearly established.

Alumina-supported Nb- and Mo-containing sulfide particles were studied using the EXAFS technique. At the $\mathrm{Nb}$ $\mathrm{K}$-edge for instance, the in-layer cation neighbours (second peak of the FT's) should be only $\mathrm{Nb}$ atoms in the case of a $\mathrm{NbS}_{2}+\mathrm{MoS}_{2}$ two phase system and in that of an interlayer solid solution (homocationic layers). For an intralayer solid solution, $\mathrm{Nb}$ and Mo atoms should be present in the cation surrounding of $\mathrm{Nb}$. The problem is that $\mathrm{Nb}$ and $\mathrm{Mo}$ backscatterers cannot be distinguished: due to their adjacent positions in the same line of the Mendeleev's table (close atomic numbers), their backscattering phases and amplitudes are nearly identical so that $\mathrm{Nb}$ - and Mo-neighbour contributions to EXAFS spectra are also nearly identical.
Consequently, the fact that simple eye observation of the FT's does not reveal any significant difference between spectra corresponding to different compositions does not provide any information. However, refinement of the EXAFS data shows that the distance from the absorbing niobium to its in-layer cation neighbours varies with the composition. More precisely, starting from $3.33 \AA$ (the $\mathrm{Nb}-\mathrm{Nb}$ distance in $\mathrm{NbS}_{2}$ ) for $\mathrm{x}=1$, it decreases with increasing Mo content. In $\mathrm{MoS}_{2}$, the Mo-Mo distance is only $3.16 \AA$. It thus appears that, as the Mo content increases, the observed decrease of the distance between the $\mathrm{Nb}$ absorbing cation and its in-layer cation neighbours reflects progressive replacement of $\mathrm{Nb}$ neighbours by Mo neighbours, which can only be explained by the intralayer solid solution model. Treatment of the EXAFS spectra recorded at the Mo K-edge shows that, starting from $3.16 \AA$ (the Mo-Mo distance in $\mathrm{MoS}_{2}$ ) for $\mathrm{x}=0$, the distance between the Mo absorbing cation and its in-layer cation neighbours increases with the $\mathrm{Nb}$ content, which again evidences the intralayer solid solution.

Different massic disulfide systems containing $\mathrm{W}$ and Mo cations were prepared, from $1273 \mathrm{~K}$ heating of $\mathrm{W}+\mathrm{Mo}+\mathrm{S}$ mixtures, and from thermal decomposition at $673 \mathrm{~K}$, under $\mathrm{H}_{2} / \mathrm{H}_{2} \mathrm{~S}(15 \%)$ atmosphere, of a thiosel precursor obtained through co-crystallization of ammonium thiomolybdate and thiotungstate [7]. For all these compounds, the EXAFS distance between the absorbing cation and its cation neighbours cannot be expected to vary significantly since the $\mathrm{W}-\mathrm{W}$ distance in $\mathrm{WS}_{2}$ and the Mo-Mo distance in $\mathrm{MoS}_{2}$ differ by less than $0.01 \AA$, which is obviously smaller than the EXAFS distance refinement accuracy. However, in this case, the two backscatterers, W and Mo, can easily be distinguished. Due to their largely different atomic numbers, the variations of their backscattering phases and amplitudes in the k-space are very different. For this reason, in the EXAFS spectra, a $\mathrm{W}$ neighbour contribution and a Mo neighbour contribution are largely different too. Actually, simple observation of the FT's shows appreciable variation of the second peak with the composition. It is a first indication of the presence of the two cations in every layer. Data refinements effectively show that reproduction of the second peak (at both $\mathrm{W} \mathrm{L}_{\mathrm{III}^{-}}$and Mo K-edge) requires presence of $\mathrm{W}$ and Mo backscatterers in relative amounts consistent with the nominal composition. It can thus be deduced that, in this case too, the structural model corresponds to the intralayer solid solution.

\section{THE PRESENT STUDY}

The present study was undertaken in order to obtain new alumina-supported catalysts containing nickel-doped $\mathrm{Mo}_{\mathrm{x}} \mathrm{W}_{(1-\mathrm{x})} \mathrm{S}_{2}$ solid solution as the active phase. For this purpose, we first checked that the solid solution can be 
retained in unsupported nickel-doped $\mathrm{Mo}_{\mathrm{x}} \mathrm{W}_{(1-\mathrm{x})} \mathrm{S}_{2}$ samples. Then, we prepared alumina supported $\mathrm{Mo}_{\mathrm{x}} \mathrm{W}_{(1-\mathrm{x})} \mathrm{S}_{2}$ and, in the last step of this study, introduced the nickel dopant for the desired supported materials to be obtained. In all cases, EXAFS measurements were performed in order to evidence the presence of the mixed cations $\left[\mathrm{Mo}_{\mathrm{x}} \mathrm{W}_{(1-\mathrm{x})} \mathrm{S}_{2}\right]$ layers characteristic of the intralayer solid solution.

\section{EXPERIMENTAL}

\subsection{Catalysts Preparation}

\subsubsection{Unsupported Samples}

$\mathrm{Mo}_{\mathrm{x}} \mathrm{W}_{(1-\mathrm{x})} \mathrm{S}_{2}$ compounds were prepared using ammonium tetrathiomolybdate $\left(\mathrm{NH}_{4}\right)_{2} \mathrm{MoS}_{4}$ and ammonium tetrathiotungstate $\left(\mathrm{NH}_{4}\right)_{2} \mathrm{WS}_{4}$ salt precursors. Ammonium tetrathiomolybdate and ammonium tetrathiotungstate were prepared and characterized according to the procedures previously described [8-10]. Synthesized $\left(\mathrm{NH}_{4}\right)_{2} \mathrm{WS}_{4}$ and $\left(\mathrm{NH}_{4}\right)_{2} \mathrm{MoS}_{4}$, taken in various proportions, were then dissolved in water. The solvent was progressively removed under vacuum $(\mathrm{T}=333 \mathrm{~K}$ ). The solids resulting from this cocrystallization were then heated for two hours at $673 \mathrm{~K}$ under a $\mathrm{H}_{2} / \mathrm{H}_{2} \mathrm{~S}(15 \%)$ flow $(6 \mathrm{~L} / \mathrm{h})$ in order to obtain the $\mathrm{MoS}_{2}$, $\mathrm{Mo}_{0.5} \mathrm{~W}_{0.5} \mathrm{~S}_{2}$, and $\mathrm{WS}_{2}$ compounds.

The nickel promoter was then introduced with an atomic ratio $\mathrm{Ni} /(\mathrm{Ni}+\mathrm{Mo}+\mathrm{W})=0.3$. The nitrate precursor salt $\mathrm{Ni}\left(\mathrm{NO}_{3}\right)_{2}, 6 \mathrm{H}_{2} \mathrm{O}$ was first dissolved in acetone. Then, the solution was impregnated on $\mathrm{MoS}_{2}, \mathrm{WS}_{2}$, and $\mathrm{Mo}_{0.5} \mathrm{~W}_{0.5} \mathrm{~S}_{2}$ compounds. After 8 hours of maturation, the solid was then dried at $313 \mathrm{~K}$ overnight and treated for two hours at $673 \mathrm{~K}$ under $\mathrm{H}_{2} / \mathrm{H}_{2} \mathrm{~S}(15 \%)$, flow $(6 \mathrm{~L} / \mathrm{h})$. These Ni-promoted $\mathrm{MoS}_{2}, \mathrm{WS}_{2}$, and $\mathrm{Mo}_{0.5} \mathrm{~W}_{0.5} \mathrm{~S}_{2}$ unsupported sulfides are respectively called NiMo, NiW, and NiMoW.

\subsubsection{Supported Catalysts}

$\gamma-\mathrm{Al}_{2} \mathrm{O}_{3}$ (specific surface area: $250 \mathrm{~m}^{2} \cdot \mathrm{g}^{-1}$, porous volume: $0.51 \mathrm{~cm}^{3} \cdot \mathrm{g}^{-1}$ ) was first crushed and sieved in the $80-125 \mu \mathrm{m}$ range. The catalysts were prepared by incipient wetness coimpregnation of the support with solutions of ammonium heptamolybdate $\left(\mathrm{NH}_{4}\right)_{6} \mathrm{Mo}_{7} \mathrm{O}_{24}, 4 \mathrm{H}_{2} \mathrm{O}$ and ammonium metatungstate $\left(\mathrm{NH}_{4}\right)_{6} \mathrm{H}_{2} \mathrm{~W}_{12} \mathrm{O}_{40}, 4 \mathrm{H}_{2} \mathrm{O}$. Before impregnation, the $\mathrm{pH}$ of the solutions was adjusted to 9.5 with diluted ammonia for monomeric species $\left(\mathrm{WO}_{4}{ }^{2-}\right.$ or $\mathrm{MoO}_{4}{ }^{2-}$ ) to be predominant [11]. Effectively, introduction of Mo and $\mathrm{W}$ as anionic monomers might be a favourable factor for the obtention of an intralayer solid solution since it limits the risk of monocationic seeds formation. The total molar amount of metal impregnated on the alumina (Mo, W or $\mathrm{Mo}+\mathrm{W}$ ) was kept constant (see Table 2).

The promoted catalysts were prepared through coimpregnation of the alumina support by solutions of $\left(\mathrm{NH}_{4}\right)_{6} \mathrm{~W}_{12} \mathrm{O}_{39}, \mathrm{xH}_{2} \mathrm{O},\left(\mathrm{NH}_{4}\right)_{6} \mathrm{Mo}_{7} \mathrm{O}_{24}, 4 \mathrm{H}_{2} \mathrm{O}$, and $\mathrm{Ni}\left(\mathrm{NO}_{3}\right)_{2}$, $6 \mathrm{H}_{2} \mathrm{O}$, at a $\mathrm{pH}$ adjusted to 9.5 . Nickel nitrate was introduced in the expected optimal ratio $\mathrm{Ni} /(\mathrm{Ni}+\mathrm{Mo}+\mathrm{W})=0.3$.

After coimpregnation and maturation, unpromoted and promoted catalysts were oven-dried at overnight at $393 \mathrm{~K}$ and calcined in air at $773 \mathrm{~K}$ during 2 hours. The catalysts were then sulfided in a flow reactor $(6 \mathrm{~L} / \mathrm{h})$, at $723 \mathrm{~K}$ during 2 hours, under $\mathrm{H}_{2} / \mathrm{H}_{2} \mathrm{~S}(10 \%)$.

\subsection{Catalysts Characterization}

XRD patterns of samples were recorded using a Bruker

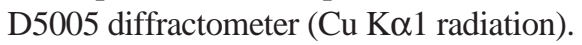

High resolution electron microscopy was performed using a JEOL 2010 TEM microscope (point to point resolution $0.19 \mathrm{~nm}$ ) equipped with a EDXS Link-Isis detector. Such detector analyses the energy of the X-ray generated by innershell ionizations of the atoms in the material by a convergent incident electron probe (smallest probe available $1 \mathrm{~nm}$ ). For sample preparation, the catalysts were ultrasonically dispersed in ethanol and the suspension was then collected on a carbon-coated copper grid.

EXAFS spectra were recorded at the Laboratoire d'Utilisation du Rayonnement Electromagnétique (LURE), the French Synchrotron Laboratory, on the XAS 13

TABLE 2

Characteristics of alumina-supported $\mathrm{MoS}_{2}, \mathrm{~W}_{0.50} \mathrm{Mo}_{0.50} \mathrm{~S}_{2}, \mathrm{WS}_{2}$ and corresponding Ni-doped samples: atom and weight $\%$ loadings, average length and stacking obtained from TEM

\begin{tabular}{|c|c|c|c|c|c|c|c|c|}
\hline & n (Mo) & $\mathrm{n}(\mathrm{W})$ & $\mathrm{n}(\mathrm{Ni})$ & $\% \mathrm{Mo}$ & $\% \mathrm{~W}$ & $\% \mathrm{Ni}$ & $\mathrm{N}$ & $1(\mathrm{~nm})$ \\
\hline $\mathrm{MoS}_{2} / \mathrm{Al}_{2} \mathrm{O}_{3}$ & 1.04 & - & - & 8.6 & - & - & 1.6 & 2.2 \\
\hline $\mathrm{Mo}_{0.50} \mathrm{~W}_{0.50} \mathrm{~S}_{2} / \mathrm{Al}_{2} \mathrm{O}_{3}$ & 0.52 & 0.52 & - & 4.3 & 7.7 & - & 2.0 & 2.0 \\
\hline $\mathrm{WS}_{2} / \mathrm{Al}_{2} \mathrm{O}_{3}$ & - & 1.04 & - & - & 15.4 & - & 1.5 & 2.5 \\
\hline $\mathrm{Ni}-\mathrm{MoS}_{2} / \mathrm{Al}_{2} \mathrm{O}_{3}$ & 1.04 & - & 0.45 & 8.3 & - & 2.0 & 1.7 & 2.5 \\
\hline $\mathrm{Ni}-\mathrm{Mo}_{0.50} \mathrm{~W}_{0.50} \mathrm{~S}_{2} / \mathrm{Al}_{2} \mathrm{O}_{3}$ & 0.52 & 0.52 & 0.45 & 4.3 & 7.7 & 2.1 & 1.6 & 2.3 \\
\hline $\mathrm{Ni}-\mathrm{WS}_{2} / \mathrm{Al}_{2} \mathrm{O}_{3}$ & - & 1.04 & 0.45 & - & 15.4 & 2.0 & 1.6 & 3.0 \\
\hline
\end{tabular}

$\mathrm{n}(\mathrm{Mo}), \mathrm{n}(\mathrm{W}), \mathrm{n}(\mathrm{Ni}): \mathrm{mmol} / \mathrm{g} \mathrm{Al} \mathrm{O}_{3} ; \% \mathrm{Mo}, \% \mathrm{~W}, \% \mathrm{Ni}$ : weight percent.

** N, $1(\mathrm{~nm})$ : stacking and length of the sulfide obtained from MET. 
spectrometer, using a Si (111) monochromator for the tungsten $\mathrm{L}_{\mathrm{III}}$ edge (10100-11200 eV, $2 \mathrm{eV}$ step, 2 s per point, sum of three spectra) and a $\mathrm{Ge}$ (400) one for the molybdenum K-edge (19800-21000 eV, $4 \mathrm{eV}$ step, 2 s per point, sum of three spectra). The storage ring (DCI) used $1.85 \mathrm{GeV}$ positrons with an average intensity of $250 \mathrm{~mA}$. For the sample preparation, pellets were pressed using powder quantities calculated in order to achieve suitable absorption coefficient and edge jump. Data were collected at $80 \mathrm{~K}$ in the transmission mode by measurement of the beam intensities $\mathrm{I}_{0}$ and I, respectively before and after passing through the sample, using ionization chambers.

Standard analysis of the EXAFS spectra (normalization, background removal, Fourier transformation, and curve fitting) were carried out using the SEDEM software [12] with FEFF [13] theoretical phase and amplitude functions. The curve fitting procedure was performed in $R$-space. Fourier transformation of the normalized $k^{3}$-weighted EXAFS signal was performed over the 2.5-16 $\AA^{-1} k$-range with Kaiser window functions. Coordination numbers $(\mathrm{N})$, interatomic distances $(\mathrm{R})$, Debye-Waller parameters $\left(\sigma^{2}\right)$, and energy shifts $\left(\Delta \mathrm{E}_{0}\right)$, were used as variables in the fitting procedure. Scale factors $\mathrm{S}_{0}{ }^{2}$ were fixed at 0.8. FEFF6 was also used to calculate for Mo-W and W-Mo (absorbing atombackscatterer) pairs the backscattering amplitudes and phase shifts required for the fitting procedures [7].

\section{RESULTS AND DISCUSSION}

\subsection{The $\mathrm{Mo}_{(1-\mathrm{x})} \mathrm{W}_{\mathrm{x}} \mathrm{S}_{2}$ Unsupported Disulfides}

The X-ray diffraction patterns of the unsupported $\mathrm{Mo}_{\mathrm{x}} \mathrm{W}_{(1-\mathrm{x})} \mathrm{S}_{2}$ compounds (prepared from the co-crystallized thiosalts) correspond to the $\mathrm{MoS}_{2}$ or $\mathrm{WS}_{2}$ hexagonal structure. However, important line broadening evidences poor crystalline organization, as expected for compounds obtained through a rather low temperature synthesis route. The diffractograms of the nickel-doped samples remain characteristic of a dispersed $\mathrm{MS}_{2}$-like structure (see Fig. 1).

For all the unsupported catalysts (undoped and doped), the average stacking determined from the linewidth of the (002) reflection (Table 3) ranges from 5 to $8\left[\mathrm{MS}_{2}\right]$ layers per crystallite. The presence of the promoter does not affect this parameter except for the NiMo catalyst.

The Fourier transforms (FT's) of the EXAFS spectra recorded at the Mo K-edge for the non-promoted $\mathrm{MoS}_{2}$ and $\mathrm{Mo}_{0.5} \mathrm{~W}_{0.5} \mathrm{~S}_{2}$ and promoted Ni-MoS $\mathrm{S}_{2}$ and Ni-Mo $\mathrm{Mo}_{0.5} \mathrm{~W}_{0.5} \mathrm{~S}_{2}$ unsupported sulfides are given Figure 2, respectively a) and b).

The first peak of all the four FT's corresponds to the expected anionic surrounding of molybdenum and is fairly reproduced with $\approx 6$ sulfur neighbours at a distance $\mathrm{d} \approx 2.40 \AA$. The second peak reflects the cationic environment of molybdenum. For $\mathrm{MoS}_{2}$, it can be reproduced, as expected,

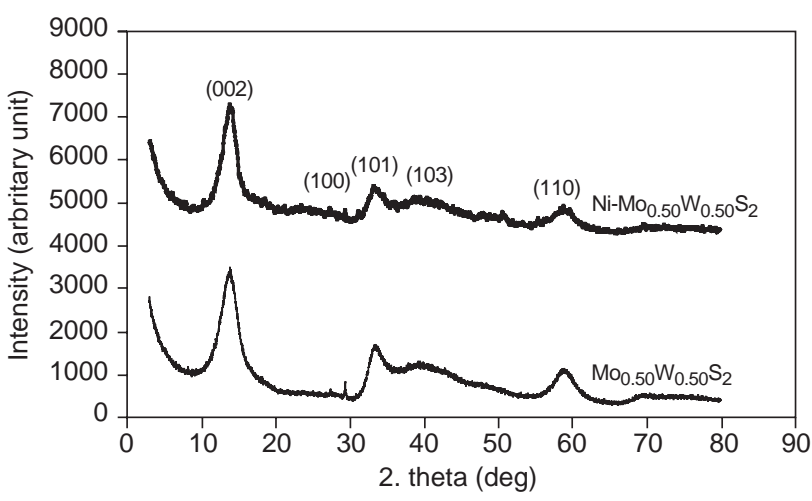

Figure 1

X-ray diffraction patterns of unsupported $\mathrm{W}_{0.50} \mathrm{Mo}_{0.50} \mathrm{~S}_{2}$ and $\mathrm{Ni}-\mathrm{W}_{0.50} \mathrm{Mo}_{0.50} \mathrm{~S}_{2}$
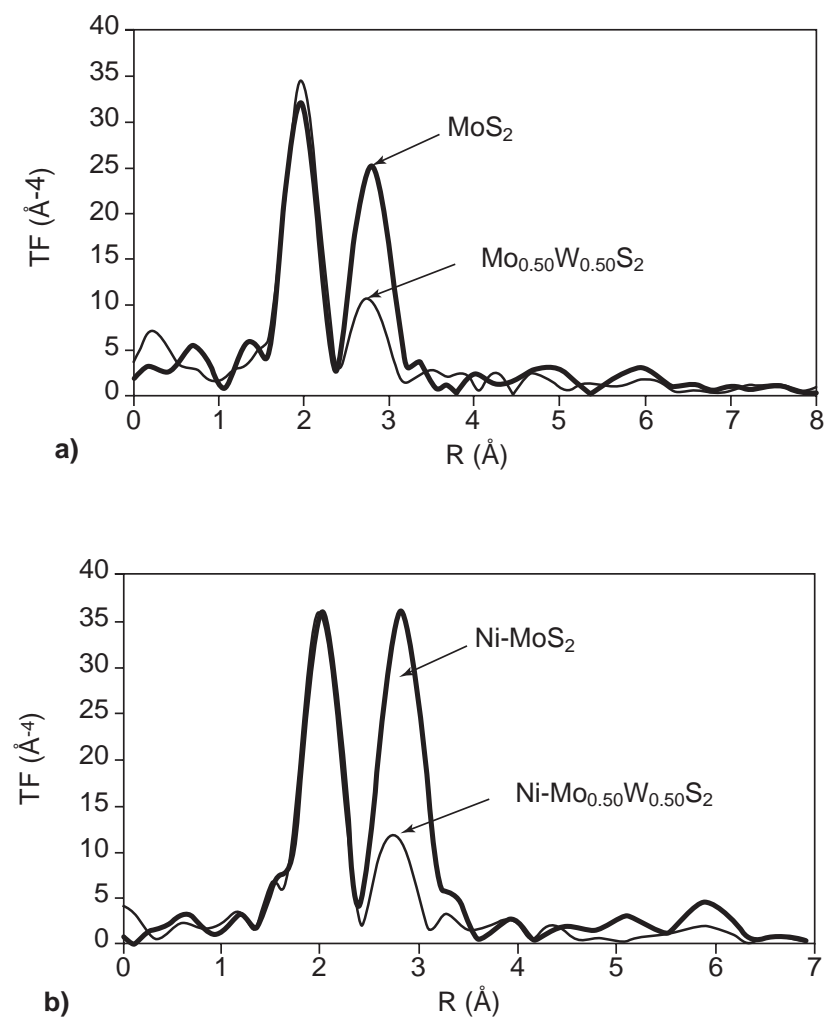

Figure 2

a) Fourier transforms obtained at the Mo K-edge for $\mathrm{MoS}_{2}$ and $\mathrm{W}_{0.50} \mathrm{Mo}_{0.50} \mathrm{~S}$; b) Fourier transforms obtained at the Mo $\mathrm{K}$-edge for $\mathrm{Ni}-\mathrm{MoS}_{2}$ and $\mathrm{Ni}-\mathrm{W}_{0.50} \mathrm{Mo}_{0.50} \mathrm{~S}_{2}$.

considering $\approx 6$ molybdenum neighbours $(\mathrm{N}(\mathrm{Mo})=5.9$, Table 4). Its intensity noticeably decreases from $\mathrm{MoS}_{2}$ to $\mathrm{Mo}_{0.5} \mathrm{~W}_{0.5} \mathrm{~S}_{2}$ which suggests for the latter presence of a Mo-W contribution which attenuates the Mo-Mo one [7]. Effectively (Table 4), refinement of the EXAFS spectrum of $\mathrm{Mo}_{0.5} \mathrm{~W}_{0.5} \mathrm{~S}_{2}$ shows that, in this case, the cationic in-plane 


\section{TABLE 3}

Average stacking $\mathrm{n}_{\text {stack }}$ deduced from the linewidth (Scherrer formula) of the (002) reflection of the unsupported samples

\begin{tabular}{l|c}
\hline & $\mathrm{n}_{\text {stack }}$ \\
\hline $\mathrm{MoS}_{2}$ & 5 \\
$\mathrm{Mo}_{0.50} \mathrm{~W}_{0.50} \mathrm{~S}_{2}$ & 5 \\
$\mathrm{WS}_{2}$ & 9 \\
$\mathrm{Ni}^{-\mathrm{MoS}_{2}}$ & 8 \\
$\mathrm{Ni}_{2} \mathrm{Mo}_{0.50} \mathrm{~W}_{0.50} \mathrm{~S}_{2}$ & 5 \\
$\mathrm{Ni}-\mathrm{WS}_{2}$ & 9 \\
\hline
\end{tabular}

environment of molybdenum contains both molybdenum $(\mathrm{N}(\mathrm{Mo})=3.3)$ and tungsten $(\mathrm{N}(\mathrm{W})=2.1)$, which allows $\left[\mathrm{MS}_{2}\right]$ heterocationic layers, an consequently intralayer solid solution, to be identified. Taking into account the estimated error on the refined $\mathrm{N}$ values, the $\mathrm{N}(\mathrm{W}) / \mathrm{N}(\mathrm{Mo})$ ratio is compatible with the nominal $\mathrm{Mo}_{0.5} \mathrm{~W}_{0.5} \mathrm{~S}_{2}$ formula.

Concerning now the promoted Ni-MoS 2 and Ni$\mathrm{Mo}_{0.5} \mathrm{~W}_{0.5} \mathrm{~S}_{2}$ samples, the intensity of the second peak of the FT (Fig. 2b) is also obviously reduced from the former to the latter. In this case too, refinement of the EXAFS spectra (Table 4) demonstrates the presence of both molybdenum $(\mathrm{N}(\mathrm{Mo})=2.7)$ and tungsten $(\mathrm{N}(\mathrm{W})=1.4)$ in every layer. Thus, for the unsupported $\mathrm{Mo}_{\mathrm{x}} \mathrm{W}_{(1-\mathrm{x})} \mathrm{S}_{2}$ disulfides, the intralayer solid solution structure is retained in the nickeldoped samples.

\subsection{The $\mathrm{Mo}_{(1-\mathrm{x})} \mathrm{W}_{\mathrm{x}} \mathrm{S}_{2}$ Disulfides Supported on Alumina}

Well-dispersed slabs, with stacking lower than two layers per particle, are evidenced by TEM characterization for the $\mathrm{MoS}_{2} / \mathrm{Al}_{2} \mathrm{O}_{3}, \mathrm{Mo}_{0.5} \mathrm{~W}_{0.5} \mathrm{~S}_{2} / \mathrm{Al}_{2} \mathrm{O}_{3}, \mathrm{WS}_{2} / \mathrm{Al}_{2} \mathrm{O}_{3}$ catalysts and the promoted ones (Table 2, Figs 3 and 4). Average stacking and length values are given Table 2 . The morphologies of the unpromoted and promoted catalysts are thus nearly identical.

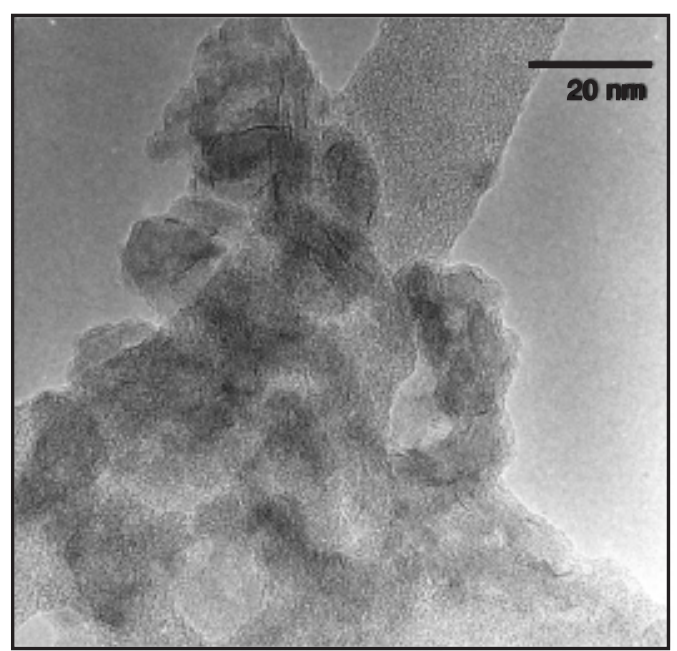

Figure 3

TEM picture of $\mathrm{W}_{0.50} \mathrm{Mo}_{0.50} \mathrm{~S}_{2} / \mathrm{Al}_{2} \mathrm{O}_{3}$.

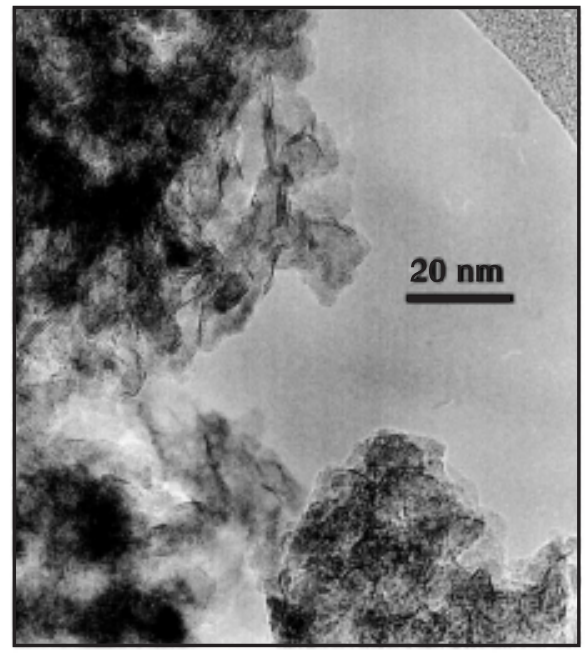

Figure 4

TEM picture of $\mathrm{Ni}-\mathrm{W}_{0.50} \mathrm{Mo}_{0.50} \mathrm{~S}_{2} / \mathrm{Al}_{2} \mathrm{O}_{3}$ sample.

TABLE 4

EXAFS refinement results (Mo K-edge): characteristics of the cationic in-plane environment of molybdenum in $\mathrm{MoS}_{2}, \mathrm{~W}_{050} \mathrm{Mo}_{050} \mathrm{~S}_{2}, \mathrm{Ni}-\mathrm{MoS}_{2}$, and Ni- $\mathrm{W}_{050} \mathrm{Mo}_{050} \mathrm{~S}_{2}$ unsupported compounds

\begin{tabular}{l|c|c|c|c|c|c|c|c}
\cline { 2 - 9 } & \multicolumn{4}{c|}{ Mo shell } & \multicolumn{4}{c}{ W shell } \\
\cline { 2 - 10 } & $\begin{array}{c}\mathrm{R}(\mathrm{Mo}) \\
(\AA)\end{array}$ & $\mathrm{N}(\mathrm{Mo})$ & $\begin{array}{c}\mathrm{J}^{2} .10^{+3} \\
\left(\AA^{2}\right)\end{array}$ & $\begin{array}{c}\Delta \mathrm{E}_{0} \\
(\mathrm{eV})\end{array}$ & $\begin{array}{c}\mathrm{R}(\mathrm{W}) \\
(\AA)\end{array}$ & $\mathrm{N}(\mathrm{W})$ & $\begin{array}{c}\mathrm{J}^{2} .10^{+3} \\
\left(\AA^{2}\right)\end{array}$ & $\begin{array}{c}\Delta \mathrm{E}_{0} \\
(\mathrm{eV})\end{array}$ \\
\hline $\mathrm{MoS}_{2}$ & 3.14 & 5.9 & 4.24 & -1.6 & - & - & - & - \\
$\mathrm{W}_{0.50} \mathrm{Mo}_{0.50} \mathrm{~S}_{2}$ & 3.16 & 3.3 & 4.45 & 2.4 & 3.17 & 2.1 & 4.7 & 6.9 \\
$\mathrm{Ni}_{2}-\mathrm{MoS}_{2}$ & 3.16 & 4.4 & 6.1 & 1.1 & - & - & - & - \\
$\mathrm{Ni}_{2} \mathrm{Mo}_{0.50} \mathrm{~W}_{0.50} \mathrm{~S}_{2}$ & 3.17 & 2.7 & 3.24 & 2.4 & 3.15 & 1.4 & 2.3 & -4 \\
\hline
\end{tabular}



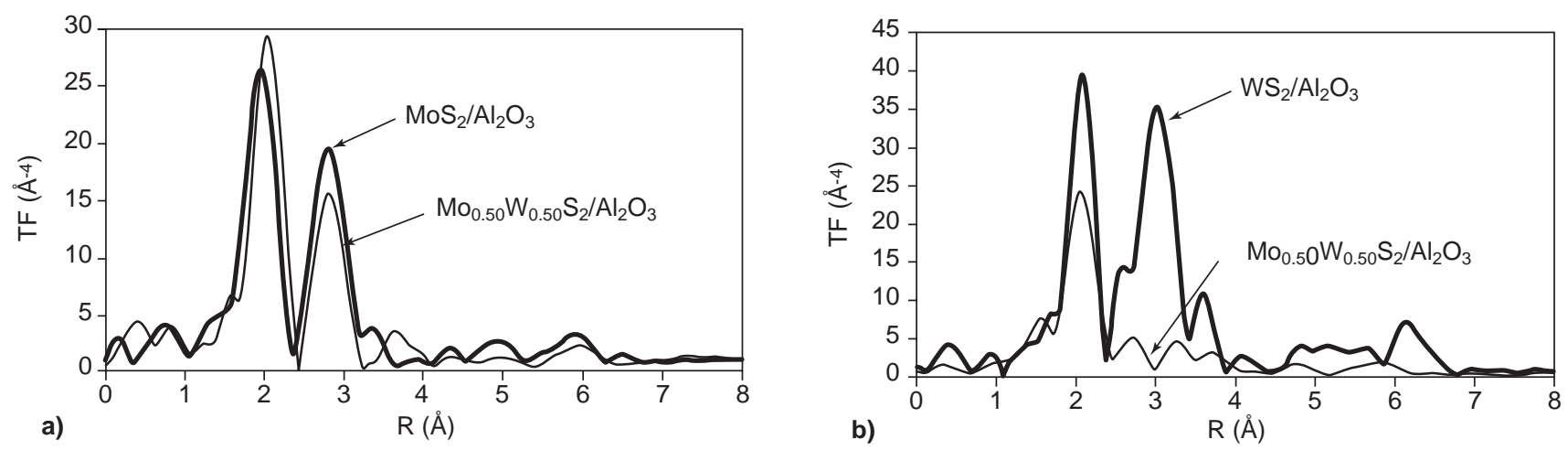

Figure 5

a) Fourier transforms obtained at the Mo K-edge for $\mathrm{MoS}_{2} / \mathrm{Al}_{2} \mathrm{O}_{3}$ and $\mathrm{W}_{0.50} \mathrm{Mo}_{0.50} \mathrm{~S}_{2} / \mathrm{Al}_{2} \mathrm{O}_{3}$; b) Fourier transforms obtained at the $\mathrm{W} \mathrm{L}_{\mathrm{III}}$-edge for $\mathrm{WS}_{2} / \mathrm{Al}_{2} \mathrm{O}_{3}$ and $\mathrm{W}_{0.50} \mathrm{Mo}_{0.50} \mathrm{~S}_{2} / \mathrm{Al}_{2} \mathrm{O}_{3}$.

EDS characterization performed with a probe as focalised as possible systematically allows presence of both molybdenum and tungsten to be evidenced, which suggests presence of a solid solution. However, only EXAFS can give unambiguous evidence of this structural arrangement.

Figure 5 displays the FT's of the EXAFS spectra recorded at the Mo K-edge (Fig. 5a) and at the $\mathrm{W} \mathrm{L}_{\mathrm{III}}$-edge (Fig. 5b) for the $\mathrm{MoS}_{2} / \mathrm{Al}_{2} \mathrm{O}_{3}, \mathrm{Mo}_{0.5} \mathrm{~W}_{0.5} \mathrm{~S}_{2} / \mathrm{Al}_{2} \mathrm{O}_{3}$ and $\mathrm{WS}_{2} / \mathrm{Al}_{2} \mathrm{O}_{3}$ undoped sulfides. The first peak of the FT corresponds to the expected anionic surrounding of the cations and is fairly reproduced with $\approx 6$ sulfur neighbors at a distance $\mathrm{R} \approx 2.40 \AA$.

At the Mo K-edge, the intensity of the second peak of the FT (contribution of the cation neighbours), does not decrease a lot from $\mathrm{MoS}_{2} / \mathrm{Al}_{2} \mathrm{O}_{3}$ to $\mathrm{Mo}_{0.5} \mathrm{~W}_{0.5} \mathrm{~S}_{2} / \mathrm{Al}_{2} \mathrm{O}_{3}$. This is contrary to what was observed for the unsupported $\mathrm{Mo}_{(1-\mathrm{x})} \mathrm{W}_{\mathrm{x}} \mathrm{S}_{2}$ sulfides, for the supported $\mathrm{Mo}_{(1-\mathrm{x})} \mathrm{W}_{\mathrm{x}} \mathrm{S}_{2}$ sulfides, the simple observation of the FT thus does not evidence the existence of an intralayer $\mathrm{Mo}_{0.5} \mathrm{~W}_{0.5} \mathrm{~S}_{2}$ solid solution and rather suggests presence of $\left[\mathrm{MoS}_{2}\right]$ layers.

However, the aspect of the cationic environment signal observed on the FT obtained for $\mathrm{Mo}_{0.5} \mathrm{~W}_{0.5} \mathrm{~S}_{2} / \mathrm{Al}_{2} \mathrm{O}_{3}$ at the $\mathrm{W} \mathrm{L}_{\mathrm{III}}$-edge is rather different: it is split into two peaks. This splitting can be related to the coexistence of a W-W contribution and a W-Mo one. Effectively, W-W and W-Mo signals have nearly opposite phases so that the corresponding peak positions are different despite the nearly identical cation-cation distances in $\mathrm{MoS}_{2}$ and $\mathrm{WS}_{2}(3.16 \mathrm{~A})$. The $\mathrm{W} \mathrm{L}_{\mathrm{III}}$-edge FT thus suggests presence of the heterocationic layers of the intralayer solid solution.

Coming back to the Mo K-edge, refinement of the EXAFS spectrum of $\mathrm{MoS}_{2} / \mathrm{Al}_{2} \mathrm{O}_{3}$ (Table 5) shows that the cationic in-plane environment of molybdenum contains only molybdenum, as expected. However, the refined neighbour number $(\mathrm{N}(\mathrm{Mo})=3.5)$ is significantly lower than in the case of the massic samples $(\mathrm{N} \approx 6)$. This reduction does not reflect effective reduction of the neighbour number: it can be related to the high dispersion of the active sulfide phase on the support [14] which leads to under estimation of the number of cationic neighbours due to static disorder effects (similar reduction of the neighbour cation number, with similar origin, will be evidenced for all our supported samples). Considering now $\mathrm{Mo}_{0.5} \mathrm{~W}_{0.5} \mathrm{~S}_{2} / \mathrm{Al}_{2} \mathrm{O}_{3}$, calculations were undertaken first on the basis of homocationic $\left[\mathrm{MoS}_{2}\right]$ layers, in agreement with what deduced from the FT's. Simple calculation using the parameters $\mathrm{N}(\mathrm{Mo})$ and $\mathrm{d}(\mathrm{Mo}-\mathrm{Mo})$ refined for the $\mathrm{MoS}_{2} / \mathrm{Al}_{2} \mathrm{O}_{3}$ sample leads to a simulated FT

TABLE 5

EXAFS refinement results (Mo K-edge): characteristics of the cationic in-plane environment of molybdenum in alumina-supported $\mathrm{MoS}_{2}$ and $\mathrm{W}_{0.50} \mathrm{Mo}_{0.50} \mathrm{~S}_{2}$

\begin{tabular}{l|c|c|c|c|c|c|c|c}
\cline { 2 - 8 } & \multicolumn{4}{c|}{ Mo shell } & \multicolumn{4}{c}{ W shell } \\
\cline { 2 - 9 } & $\begin{array}{c}\mathrm{R}(\mathrm{Mo}) \\
(\AA)\end{array}$ & $\mathrm{N}(\mathrm{Mo})$ & $\begin{array}{c}\mathrm{J}^{2} .10^{+3} \\
\left(\AA^{2}\right)\end{array}$ & $\begin{array}{c}\Delta \mathrm{E}_{0} \\
(\mathrm{eV})\end{array}$ & $\begin{array}{c}\mathrm{R}(\mathrm{W}) \\
(\AA)\end{array}$ & $\begin{array}{c}\mathrm{N}(\mathrm{W}) \\
J^{2} .10^{+3} \\
\left(\AA^{2}\right)\end{array}$ & $\begin{array}{c}\Delta \mathrm{E}_{0} \\
(\mathrm{eV})\end{array}$ \\
\hline $\mathrm{MoS}_{2} / \mathrm{Al}_{2} \mathrm{O}_{3}$ & 3.15 & 3.5 & 3.4 & 1.0 & - & - & - & - \\
$\mathrm{Mo}_{0.50} \mathrm{~W}_{0.50} \mathrm{~S}_{2} / \mathrm{Al}_{2} \mathrm{O}_{3}$ & 3.15 & 2.2 & 2.7 & 15.0 & 3.16 & 1.2 & 2.7 & 18.8 \\
\hline
\end{tabular}

$\Delta \mathrm{R}=+/-4.10^{-3} \AA, \Delta \mathrm{N}=+/-0.3, \Delta(\Delta \mathrm{Eo})=+/-0.7 \mathrm{eV}, \Delta\left(\mathrm{J}^{2}\right)=+/-0.6 \cdot 10^{-3} \AA^{2}$. 
imaginary part completely different from the experimental one. The parameters were then refined but the results of this refinement are not consistent $(\mathrm{d}(\mathrm{Mo}-\mathrm{Mo})=3.10 \AA$, $\mathrm{N}(\mathrm{Mo})=1.8)$ with the $\mathrm{MoS}_{2}$ structure. The only solution was then to introduce both molybdenum and tungsten as molybdenum neighbours. Under these conditions, correct reproduction of the experimental signal was achieved with $\mathrm{N}(\mathrm{Mo})=2.2$ and $\mathrm{N}(\mathrm{W})=1.2$, in reasonable agreement with the nominal formula. In fact, the contribution of the $\mathrm{W}$ neighbours can be seen in the Fourier-filtered EXAFS spectrum of the $\mathrm{Mo}_{0.5} \mathrm{~W}_{0.5} \mathrm{~S}_{2} / \mathrm{Al}_{2} \mathrm{O}_{3}$ sample as compared to that of the $\mathrm{MoS}_{2} / \mathrm{Al}_{2} \mathrm{O}_{3}$ one in the range of 10 to $12 \AA^{-1}$ as shown in Figure 6. In this case too, the structural arrangement thus corresponds to the intralayer solid solution. This highlights the danger of drawing premature conclusions on the only basis of FT observation.

At the $\mathrm{W} \mathrm{L}_{\mathrm{III}}$-edge (Table 6), tungsten is found to be surrounded by 4.3 tungsten neighbours in $\mathrm{WS}_{2} / \mathrm{Al}_{2} \mathrm{O}_{3}$ while, in $\mathrm{Mo}_{0.5} \mathrm{~W}_{0.5} \mathrm{~S}_{2} / \mathrm{Al}_{2} \mathrm{O}_{3}$, its cationic in-plane environment contains both molybdenum and tungsten in relative amounts
$(\mathrm{N}(\mathrm{Mo})=2.0$ and $\mathrm{N}(\mathrm{W})=2.6)$ consistent with the formula, which confirms the existence of the heterocationic layers of the solid solution.

The FT's of the EXAFS spectra recorded at the Mo K-edge for the promoted $\mathrm{NiMoS}_{2} / \mathrm{Al}_{2} \mathrm{O}_{3}$ and $\mathrm{NiMo}_{0.5} \mathrm{~W}_{0.5} \mathrm{~S}_{2} / \mathrm{Al}_{2} \mathrm{O}_{3}$ catalysts are given Figure 7. The intensity of the second peak is this time significantly reduced from the former to the latter which suggests that, in $\mathrm{NiMo}_{0.5} \mathrm{~W}_{0.5} \mathrm{~S}_{2} / \mathrm{Al}_{2} \mathrm{O}_{3}$, every layer contains both molybdenum and tungsten. The EXAFS spectra refinements (Table 7) confirm the heterocationic nature of the layers $(\mathrm{N}(\mathrm{Mo})=2.9, \mathrm{~N}(\mathrm{~W})=1.6)$. The Fourierfiltered EXAFS spectrum of the $\mathrm{NiMo}_{0.5} \mathrm{~W}_{0.5} \mathrm{~S}_{2} / \mathrm{Al}_{2} \mathrm{O}_{3}$ sample fitted with a model $\mathrm{Mo}_{\mathrm{abs}}-\mathrm{S}-(\mathrm{Mo}, \mathrm{W})$ is given Figure 8. As in the case of unpromoted systems, the presence of $\mathrm{W}$ neighbours is clearly seen in the range of 1.0 to $1.2 \mathrm{~nm}^{-1}$. The similarity of the experimental and fitted spectra confirms the validity of the model used. Consequently, the presence of the nickel promoter does not disrupt the formation of the intralayer $\mathrm{Mo}_{\mathrm{x}} \mathrm{W}_{(1-\mathrm{w})} \mathrm{S}_{2}$ solid solution.
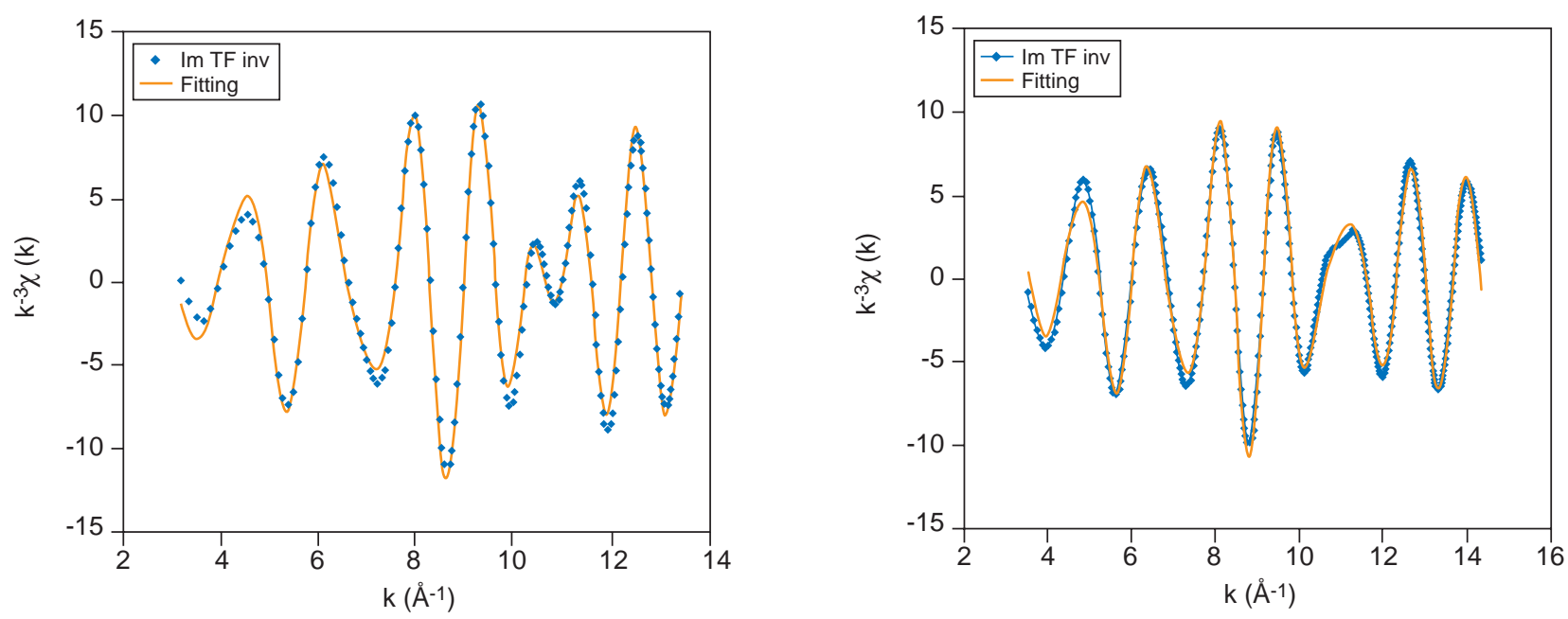

Figure 6

Fourier-filtered EXAFS k3. $\chi(\mathrm{k})$ spectra (diamonds, fitting: solid curve) of $\mathrm{MoS}_{2}$ on alumina (left) and that of the $\mathrm{Mo}_{0.50} \mathrm{~W}_{0.5} \mathrm{~S}_{2}$ supported on alumina sample (right) fitted with a model $\mathrm{Mo}_{\mathrm{abs}}-(\mathrm{S}, \mathrm{Mo}, \mathrm{W})_{\text {backscatters }}$.

TABLE 6

EXAFS refinement results ( $\mathrm{W} \mathrm{L}_{\mathrm{III}}$-edge): characteristics of the cationic in-plane environment of molybdenum in alumina-supported $\mathrm{WS}_{2}$ and $\mathrm{W}_{0.50} \mathrm{Mo}_{0.50} \mathrm{~S}_{2}$

\begin{tabular}{l|c|c|c|c|c|c|c|c}
\cline { 2 - 9 } & \multicolumn{4}{c|}{ Mo shell } & \multicolumn{4}{c}{ W shell } \\
\cline { 2 - 10 } & $\begin{array}{c}\mathrm{R}(\mathrm{Mo}) \\
(\AA)\end{array}$ & $\mathrm{N}(\mathrm{Mo})$ & $\begin{array}{c}\mathrm{J}^{2} .10^{+3} \\
\left(\AA^{2}\right)\end{array}$ & $\begin{array}{c}\Delta \mathrm{E}_{0} \\
(\mathrm{eV})\end{array}$ & $\begin{array}{c}\mathrm{R}(\mathrm{W}) \\
(\AA)\end{array}$ & $\mathrm{N}(\mathrm{W})$ & $\begin{array}{c}\mathrm{J}^{2} .10^{+3} \\
\left(\AA^{2}\right)\end{array}$ & $\begin{array}{c}\Delta \mathrm{E}_{0} \\
(\mathrm{eV})\end{array}$ \\
\hline $\mathrm{WS}_{2} / \mathrm{Al}_{2} \mathrm{O}_{3}$ & - & - & - & - & 3.15 & 4.3 & 1.8 & 7.9 \\
$\mathrm{Mo}_{0.50} \mathrm{~W}_{0.50} \mathrm{~S}_{2} / \mathrm{Al}_{2} \mathrm{O}_{3}$ & 3.18 & 2.0 & 4.0 & 14.0 & 3.16 & 2.6 & 3.7 & 6.8 \\
\hline
\end{tabular}

$\Delta \mathrm{R}=+/-4.10^{-3} \AA, \Delta \mathrm{N}=+/-0.3, \Delta(\Delta \mathrm{Eo})=+/-0.7 \mathrm{eV}, \Delta\left(J^{2}\right)=+/-0.6 .10^{-3} \AA^{2}$. 
TABLE 7

EXAFS refinement results (Mo K-edge): characteristics of the cationic in-plane environment of molybdenum in alumina-supported $\mathrm{Ni}-\mathrm{MoS}_{2}$ and $\mathrm{Ni}-\mathrm{W}_{0.50} \mathrm{Mo}_{0.50} \mathrm{~S}_{2}$

\begin{tabular}{|c|c|c|c|c|c|c|c|c|}
\hline & \multicolumn{4}{|c|}{ Mo shell } & \multicolumn{4}{|c|}{ W shell } \\
\hline & $\begin{array}{c}\mathrm{R}(\mathrm{Mo}) \\
(\AA)\end{array}$ & $\mathrm{N}(\mathrm{Mo})$ & $\begin{array}{c}J^{2} \cdot 10^{+3} \\
\left(\AA^{2}\right)\end{array}$ & $\begin{array}{l}\Delta \mathrm{E}_{0} \\
(\mathrm{eV})\end{array}$ & $\begin{array}{c}\mathrm{R}(\mathrm{W}) \\
(\AA)\end{array}$ & $\mathrm{N}(\mathrm{W})$ & $\begin{array}{c}J^{2} \cdot 10^{+3} \\
\left(\AA^{2}\right)\end{array}$ & $\begin{array}{l}\Delta \mathrm{E}_{0} \\
(\mathrm{eV})\end{array}$ \\
\hline $\mathrm{Ni}-\mathrm{MoS}_{2} / \mathrm{Al}_{2} \mathrm{O}_{3}$ & 3.16 & 3.3 & 1.2 & 2.2 & - & - & - & - \\
\hline $\mathrm{Ni}-\mathrm{Mo}_{0.50} \mathrm{~W}_{0.50} \mathrm{~S}_{2} / \mathrm{Al}_{2} \mathrm{O}_{3}$ & 3.16 & 2.9 & 2.0 & 1.3 & 3.15 & 1.6 & 2.0 & -1.7 \\
\hline
\end{tabular}

$\Delta \mathrm{R}=+/-4.10^{-3} \AA, \Delta \mathrm{N}=+/-0.3, \Delta(\Delta \mathrm{Eo})=+/-0.7 \mathrm{eV}, \Delta\left(J^{2}\right)=+/-0.6 .10^{-3} \AA^{2}$.

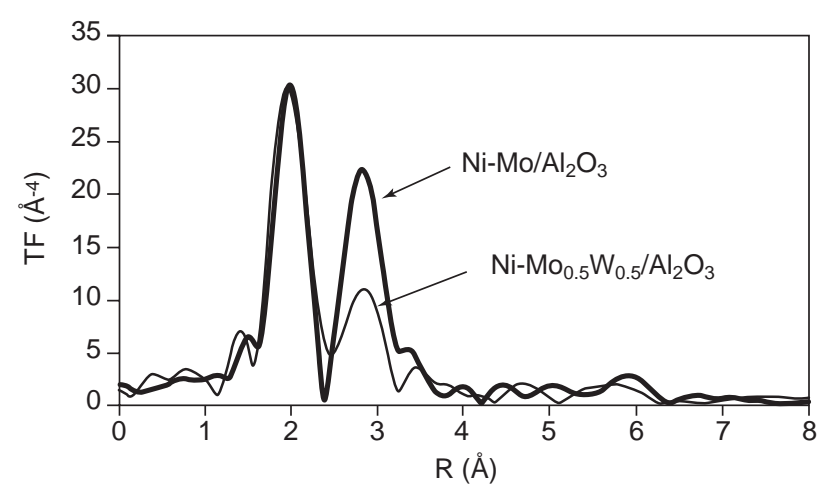

Figure 7

Fourier transforms obtained at the Mo K-edge for Ni$\mathrm{MoS}_{2} / \mathrm{Al}_{2} \mathrm{O}_{3}$ and $\mathrm{Ni}-\mathrm{W}_{0.50} \mathrm{Mo}_{0.50} \mathrm{~S}_{2} / \mathrm{Al}_{2} \mathrm{O}_{3}$.

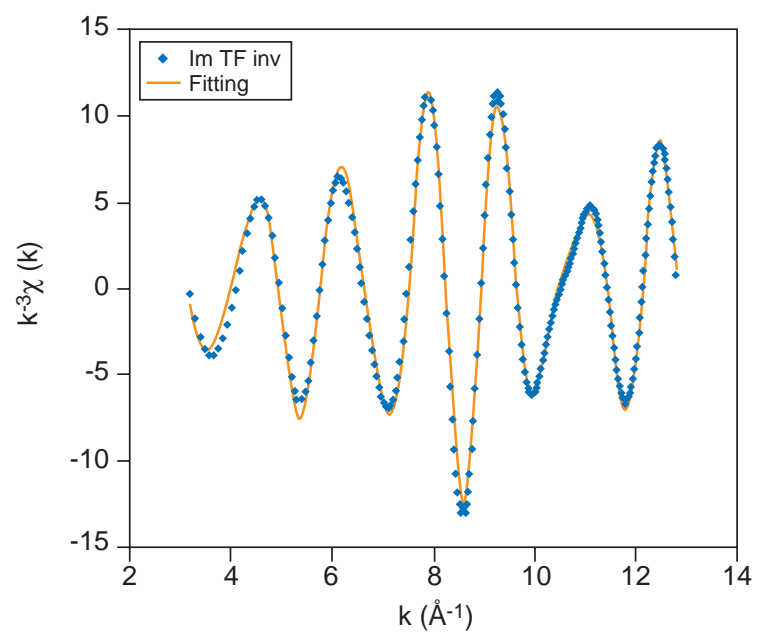

Figure 8

Mo K-edge Fourier-filtered EXAFS $\mathrm{k}^{3} \cdot \chi(\mathrm{k})$ spectrum (diamonds) of $\mathrm{Ni}-\mathrm{W}_{0.50} \mathrm{Mo}_{0.50} \mathrm{~S}_{2} / \mathrm{Al}_{2} \mathrm{O}_{3}$ fitted with three neighbour shells: $\mathrm{Mo}_{\mathrm{abs}}-\mathrm{S}, \mathrm{Mo}_{\mathrm{abs}}-\mathrm{Mo}$, and $\mathrm{Mo}_{\mathrm{abs}}-\mathrm{W}$ (solid curve).

\section{CONCLUSIONS}

The present study illustrates the unique capability of EXAFS for the determination of complex nanoscale structures such as that of $\mathrm{Mo}_{\mathrm{x}} \mathrm{W}_{(1-\mathrm{x})} \mathrm{S}_{2}$-related catalytic systems. Even if the interatomic distances are very close in the $\mathrm{MoS}_{2}$ and $\mathrm{WS}_{2}$ partners, backscattering amplitudes and phase shifts can unambiguously clarify the nature of the cationic neighbours of the absorbing atom and allow the presence of the intralayer solid solution to be demonstrated in dispersed unsupported, supported, and Ni-promoted $\mathrm{Mo}_{\mathrm{x}} \mathrm{W}_{(1-\mathrm{x})} \mathrm{S}_{2}$ catalysts.

\section{ACKNOWLEDGEMENTS}

We thank the Lure committee for providing machine-time. C. Thomazeau thanks IFP and CNRS for financial support.

\section{REFERENCES}

1 Off. J. Eur. Commun., L350, 58, (1998).

2 Chianelli, R.R., Daage, M. and Ledoux, M.J. (1994) Fundamental Studies of Transition-Metal Sulfide Catalytic Materials. Adv. Catal., 40, 177-232.

3 Norskov, J.K., Clausen, B.S. and Topsoe, H. (1992) Understanding the Trends in the Hydrodesulfurization Activity of the Transition Metal Sulfides. Catal. Lett., 13, 1-8.

4 Toulhoat, H., Raybaud, P., Kasztelan, S., Kresse, G. and Hafner, J. (1999) Transition Metals to Sulfur Binding Energies Relationship to Catalytic Activities in HDS: Back to Sabatier with First Principle Calculations. Catalysis Today, 50, 629-636.

5 Hülliger, F. (1976) In: Structural Chemistry of Layered-Type Phases, Eds Levy.

6 Gaborit, V., Allali, N., Danot, M., Geantet, C., Cattenot, M., Breysse, M. and Diehl, F. (2003) Hydrotreating Properties of Mixed $\mathrm{Nb}_{x} \mathrm{Mo}_{1} \mathrm{~S}_{2}$ alumina supported catalysts. Catalysis Today, 78, $499-505$.

7 Thomazeau, C., Geantet, C., Lacroix, M., Harlé, V., Benazeth, S., Marhic, C., and Danot, M. (2001) Two Cation Disulfide Layers in the $\mathrm{W}_{\mathrm{x}} \mathrm{Mo}_{(1-\mathrm{x})} \mathrm{S}_{2}$ Lamellar Solid Solution. J. Solid State Chem., 160, 147-155.

8 Breysse, M., Fréty, R., Lacroix, M. and Vrinat, M. (1984) Comparison of the Catalytic Properties in Hydrodesulfurization Reaction of Unsupported $\mathrm{MoS}_{2}$ and WS Catalysts: Influence of Surface Areas. React. Kinet. Catal. Lett., 26 (1-2), 97.

9 Ramanathan, K. and Weller, S.W. (1985) Characterization of Tungsten Sulfide Catalysts. J. Catal., 95, 249-259.

Alonso, G., Valle, M.D., Cruz, J., Petranovskii, V., LiceaClaverie, A. and Fuentes, S. (1998) Preparation of $\mathrm{MoS}_{2}$ 
Catalysts by in situ Decomposition of Tetraalkylammonium Thiomolybdates. Catalysis Today, 43, 117-122.

10 Diemann, E. and Müller, A. (1973) Thio and Seleno Compounds of the Transition Metals with the $\mathrm{d}^{0}$ Configuration. Coord. Chem. Rev., 10, 79-122.

11 Charlot, G. (1958) In: L'analyse quantitative et les réactions en solution, Eds Masson; Carrier, X., Thèse Université Paris VI (1998).

12 Aberdam, D. (1998) SEDEM, a Software Package for EXAFS Data Extraction and Modelling. J. Synchrotron Rad., 5, 1287-1297.
13 Rehr, J.J., Zabinsky, S.I. and Albers, R.C. (1992) High-Order Multiple-Scattering Calculations of X-Ray-Absorption Fine Structure. Phys. Rev. Letters, 69, 3397.

14 Shimada, H., Matsubayashi, N., Sato, T., Yoshimura, Y. Imamura, M., Kameoka, T. and Nishijima, A. (1993) EXAFS Study on the Dispersion of Molybdenum Sulfide Catalysts on Gamma- $\mathrm{Al}_{2} \mathrm{O}_{3}$. Catal. Lett., 20, 81 .

Final manuscript received in May 2005 